\title{
TP53 mutations in ovarian carcinomas from sporadic cases and carriers of two distinct BRCA I founder mutations; relation to age at diagnosis and survival
}

\author{
Pedro Kringen ${ }^{1}$, Yun Wang1,2,3, Vanessa Dumeaux ${ }^{1,5}$, Jahn M Nesland ${ }^{4}$, \\ Gunnar Kristensen², Anne-Lise Borresen-Dale ${ }^{1,3}$ and Anne Dorum*2
}

Address: ${ }^{1}$ Department of Genetics, The Norwegian Radium Hospital, Montebello, 0310 Oslo, Norway, ${ }^{2}$ Department of Gynecologic Oncology, The Norwegian Radium Hospital, Montebello, 0310 Oslo, Norway, ${ }^{3}$ University of Oslo, The Norwegian Radium Hospital, Montebello, 0310 Oslo, Norway, ${ }^{4}$ Department of Pathology, The Norwegian Radium Hospital, Montebello, 0310 Oslo, Norway and ${ }^{5}$ Institute of Community Medicine, University of Tromsø

Email: Pedro Kringen - pedrok@broadpark.no; Yun Wang - yun.wang@medisin.uio.no; Vanessa Dumeaux - vanessa.dumeaux@medisin.uio.no; Jahn M Nesland - j.m.nesland@medisin.uio.no; Gunnar Kristensen - gunnar.kristensen@klinmed.uio.no; Anne-Lise BorresenDale - a.l.borresen-dale@medisin.uio.no; Anne Dorum* - anne.dorum@dnr.uio.no

* Corresponding author

Published: 17 October 2005

BMC Cancer 2005, 5:134 doi:10.1/86/147|-2407-5-134
Received: 14 January 2005

Accepted: 17 October 2005

This article is available from: http://www.biomedcentral.com/I47I-2407/5/I34

(C) 2005 Kringen et al; licensee BioMed Central Ltd.

This is an Open Access article distributed under the terms of the Creative Commons Attribution License (http://creativecommons.org/licenses/by/2.0), which permits unrestricted use, distribution, and reproduction in any medium, provided the original work is properly cited.

\begin{abstract}
Background: Ovarian carcinomas from 30 BRCAI germ-line carriers of two distinct high penetrant founder mutations, 20 carrying the $1675 \mathrm{delA}$ and 10 the II 35 ins A, and 100 sporadic cases were characterized for somatic mutations in the TP53 gene. We analyzed differences in relation to BRCAI germline status, TP53 status, survival and age at diagnosis, as previous studies have not been conclusive.

Methods: DNA was extracted from paraffin embedded formalin fixed tissues for the familial cases, and from fresh frozen specimen from the sporadic cases. All cases were treated at our hospital according to protocol. Mutation analyses of exon 2 - I I were performed using TTGE, followed by sequencing.

Results: Survival rates for BRCA I-familial cases with TP53 mutations were not significantly lower than for familial cases without TP53 mutations ( $P=0.25, R R=1.64,95 \% \mathrm{Cl}[0.7 \mathrm{I}-3.78]$ ). Median age at diagnosis for sporadic (59 years) and familial (49 years) cases differed significantly $(\mathrm{p}<0.00 \mathrm{I})$ with or without TP53 mutations. Age at diagnosis between the two types of familial carriers were not significantly different, with median age of 47 for 1675 del $A$ and 52.5 for 1135 ins A carriers $(p=0.245)$. For cases $\geq 50$ years at diagnosis, a trend toward longer survival for sporadic over familial cases was observed $(p=0.08)$. The opposite trend was observed for cases $<50$ years at diagnosis.

Conclusion: There do not seem to be a protective advantage for familial BRCA I carriers without TP53 mutations over familial cases with TP53 mutations. However, there seem to be a trend towards initial advantage in survival for familial cases compared to sporadic cases diagnosed before the age of 50 both with and without TP53 mutations. However, this trend diminishes over time and for cases diagnosed $\geq 50$ years the sporadic cases show a trend towards an advantage in survival over familial cases. Although this data set is small, if confirmed, this may be a link in the evidence that the differences in ovarian cancer survival reported, are not due to the type of BRCAI mutation, but may be secondary to genetic factors shared. This may have clinical implications for follow-up such as prophylactic surgery within carriers of the two most frequent Norwegian BRCA I founder mutations.
\end{abstract}




\section{Background}

Ovarian cancer is one of the leading causes of cancerrelated death in women today. It is the $4^{\text {th }}$ most common cancer in women in Norway and accounts for $5-6 \%$ of all cancers $[1,2]$. Mean age at diagnosis for sporadic cases have been reported to 62.3 years [3], and in Norway to 65 years. Age-standardized incidence rates were $13.5 \mathrm{pr}$ 100.000 , and close to $40 \%$ of the patients is achieving 5year survival according to The Norwegian Cancer Registry (OVANOR 1991 - 1996).

Almost $10 \%$ of epithelial ovarian cancer cases are associated with dominant genetic predisposition, in most cases $(80-90 \%)$, linked to mutations in BRCA1 or BRCA2 [4$6]$. Mean age at diagnosis for these inherited cases have been reported to be from 49 to 54.3 years [3,7]. The penetrance of the disease in mutation carriers varies, and has been reported to be from $27-80 \%$ [8-10]. It should be noted that both the incidence rate for hereditary cases and the penetrance of the disease may differ depending on geographic and ethnic origin [11]. The survival rate may also vary depending on type and localization of the mutation. Some studies have reported that ovarian cancer patients carrying germ-line BRCA1 mutations have an enhanced survival rate compared to sporadic cases $[3,12-$ 14]. Other studies demonstrated only an initial survival advantage that disappeared with time, and concluded that no enhanced survival rates follows BRCA1 dysfunction [15-17]. These studies predict a survival rate for BRCA1 familial ovarian cancer that is equal to or higher than nonfamilial cases.

Both the penetrance estimates and the survival rates are based on studies in populations with strong founder effects, and may therefore be biased. The type of mutation in the BRCA1 gene may affect the timing of the diagnosis of the disease, the response to environmental exposure causing DNA damage, the efficiency of DNA repair, and the frequency of somatic mutations developing in the tumor. These factors may in turn affect the survival rate.

Mutations in the TP53 tumor suppressor gene are the most common genetic alteration in human tumors and have been suggested as a molecular marker for prognosis. TP53 encodes a nuclear phosphoprotein located at chromosome region 17 p13 involved in cell cycle arrest and DNA repair and somatic TP53 mutations are known to associate with familial ovarian cancer. In ovarian tumors from BRCA1 mutation carriers, somatic TP53 mutations are found in $60-80 \%$ of the cases [18-22]. Thirty to $50 \%$ of all ovarian cancers have been reported to harbor a TP53 mutation [18-20,23,24]. Further, in $30-85 \%$ of the sporadic ovarian carcinomas both a TP53 mutations and a somatic BRCA1/BRCA2 mutation have been found $[18,20,25]$.
These findings implicate that TP53 and BRCA1 directly interacts and may play an important role in DNA repair processes and tumor suppression [26,27]. However, despite the high frequency of mutations in the tumor suppressor gene TP53, there are several reports concluding that TP53 is not a good predictor of prognosis in sporadic ovarian cancer patients [24,28,29].

We have previously reported two Norwegian BRCA1 founder mutations; 1135insA [30] and 1675delA [11]. Carriers of these mutations show almost the same penetrance for ovarian- and breast cancer and the penetrance is also high compared to most reported BRCA1 mutation carriers. By age 50, 48\% of mutation carriers had experienced breast- and/or ovarian cancer. Mean age of ovarian cancer diagnosis was 55 years [10]. Three per cent of all Norwegian ovarian cancers are caused by either of the two founder mutations [31]. As a result of a clinical follow-up program for early diagnosis in women from breast-ovarian cancer kindreds, these two mutations may account for more than half of those with a BRCA1 mutation in Norway. The histopathological characteristics of both breast and ovarian cancer indicated an unfavorable prognosis in these mutation carriers [32].

In the present study, we have screened epithelial ovarian tumors from 30 familial cases and 100 sporadic cases for somatic mutations in the TP53 gene. The cancer treatment was according to our hospital protocol. The familial cases consisted of one group with the BRCA1 1135insA mutation and the other had the BRCA1 1675delA mutation [10]. The TP53 mutation status was correlated to survival, age at diagnosis and histopathological features.

\section{Materials}

Formalin fixed and paraffin embedded ovarian cancer tissue from 30 BRCA1 germ line mutation carriers were collected and used for DNA extraction. Of the familial cases 20 patients carried the 1675 delA mutation and another 10 patients the 1135 ins A mutation, which is a representative distribution between the two mutations in the Norwegian population. The BRCA1 carriers were from families with at least two first-degree relatives, or seconddegree relatives through male, with ovarian cancer and/or breast cancer under age 60. All cases were sampled from pedigree regardless of survival status, as ovarian cancer treatment is centralized to our hospital. Analysis of fresh frozen specimen of tumor DNA from the 100 sporadic cases sampled from 1992-2003, included in this study has previously been reported [29]. Both groups were diagnosed and treated at the Norwegian Radium Hospital according to protocol. The patient characteristics are shown in Table 1. All tumors were reviewed at our department of pathology, the familial tumors by our team pathologist, and were classified and graded according to 
Table I: Patient characteristics

\begin{tabular}{|c|c|c|c|c|}
\hline & \multirow[t]{2}{*}{ Sporadic cases } & \multicolumn{3}{|c|}{$B R C A /$ carriers } \\
\hline & & All familial cases & II35insA & 1675delA \\
\hline No of cases & 100 & 30 & 10 & 20 \\
\hline Age at diagnosis: Median & 59 & 49 & 52.5 & 47 \\
\hline range & $39-80$ & $39-80$ & $41-80$ & $39-65$ \\
\hline \multicolumn{5}{|l|}{ FIGO stage } \\
\hline$I-\|$ & $9(9.0 \%)$ & $8(26.7 \%)$ & $2(20.0 \%)$ & $6(30.0 \%)$ \\
\hline III & $65(65.0 \%)$ & 14 (46.7\%) & $5(50.0 \%)$ & $9(45.0 \%)$ \\
\hline IV & $26(26.0 \%)$ & $8(26.7 \%)$ & $3(30.0 \%)$ & $5(25.0 \%)$ \\
\hline \multicolumn{5}{|l|}{ Histology } \\
\hline Serous & $82(82.0 \%)$ & $24(80.0 \%)$ & 7 (70.0\%) & $17(85.0 \%)$ \\
\hline Mixed & $7(7.0 \%)$ & $2(6.6 \%)$ & $\mathrm{I}(10.0 \%)$ & I (5.0\%) \\
\hline Endometroid & $5(5.0 \%)$ & $3(10.0 \%)$ & I (I0.0\%) & $2(10.0 \%)$ \\
\hline Unclassified & $6(6.0 \%)$ & I (3.3\%) & I (10.0\%) & 0 \\
\hline \multicolumn{5}{|l|}{ Grade of differentiation } \\
\hline I & $7(7.0 \%)$ & 0 & 0 & 0 \\
\hline 2 & $26(26.0 \%)$ & $5(16.6 \%)$ & I (10.0\%) & $4(20.0 \%)$ \\
\hline 3 & $67(67.0 \%)$ & $24(80.0 \%)$ & $9(90.0 \%)$ & $15(75.0 \%)$ \\
\hline Unknown & 0 & I (3.3\%) & 0 & I (5.0\%) \\
\hline Survival $>5$ years & $23(23.0 \%)$ & $10(33.3 \%)$ & $3(30.0 \%)$ & 7 (35.0\%) \\
\hline TP53 mutation status & $72.0 \%$ & $53.3 \%$ & $50.0 \%$ & $55.0 \%$ \\
\hline
\end{tabular}

All tumors are epithelial adenocarcinomas

the World Health Organization (WHO) criteria. Followup time for each case was calculated from the date of diagnosis up to date of death or end of study (15 th April, 2004).

\section{Methods \\ DNA extraction and TP53 mutation analysis}

DNA was manually extracted from paraffin-embedded tissue sections of tumor material using 5 sections of $10 \mu$. A modification of the procedure described by Miller [33] was used. The modification included using as much as possible of the top water layer of the $700 \mathrm{ml} \mathrm{DNA} / \mathrm{lysis}$ buffer and $1 \mathrm{ml}$ phenol/chloroform/water mix, and repeating the extraction step once. The protocol was optimized to give high yield of good quality DNA.

Mutation analyses of exons 2-11 of the TP53 gene in the 30 cases with BRCA1 germ line mutations were performed by TTGE followed by sequencing. Primers, PCR conditions and gel running conditions were as described elsewhere [34]. Samples with aberrantly migrating bands on TTGE were isolated, submitted to a new PCR and sequenced. Analysis of the fresh frozen specimen of tumor DNA from the 100 sporadic cases has previously been reported [29].

\section{Statistical analyses}

In univariate analyses, a log rank test have been used to investigate the effect of age at diagnosis, BRCA1 and TP53 mutations on the survival rate. In multivariate analyses, Cox proportional hazards regression analysis was used. Hazard ratios (HR's) are given with 95\% confidence intervals (CI's). Statistical significance rates were set at 0.05 . The software $\mathrm{SAS}^{\circledast}$ version 8.2 was used for statistical analyses.

\section{Results}

TP53 characterizations and novel mutations

Nineteen of the 30 ovarian carcinomas showed one or more aberrant migrating bands on TTGE in one or more exons and was sequenced (Table 2). A total of 21 sequence changes were detected. Two cases had two different TP53 sequence changes in their tumors, one being a silent mutation. Nine mutations were missense mutations, four 
Table 2: TP53 mutations, survival and histopathological features for each case.

\begin{tabular}{|c|c|c|c|c|c|c|c|c|c|c|c|c|}
\hline Case & $\begin{array}{c}\text { aBRCAI } \\
\text { carrier type }\end{array}$ & Stage & bGrade & Type & TTGE & Exon & Codon & Mutation & aa change & $\begin{array}{c}\text { Age of } \\
\text { diagnosis }\end{array}$ & $\begin{array}{l}\text { cSurvival } \\
\text { months }\end{array}$ & $\begin{array}{l}\text { dVital } \\
\text { status }\end{array}$ \\
\hline 3453 & I & 3 & 2 & ser & pos & 5 & & $559+\mid G>A$ & splice & 53 & 83 & 1 \\
\hline 10 & I & 3 & 3 & ser & pos & 6 & 213 & CGA $>$ TGA & arg>stop & 65 & 22 & 3 \\
\hline 2857 & I & 3 & 3 & ser & pos & 6 & 213 & CGA $>T G A$ & arg>stop & 53 & 83 & 3 \\
\hline 4 & I & 4 & 3 & ser & pos & 6 & 216 & GTG>ATG & $\mathrm{val}>\mathrm{met}$ & 59 & 11 & 3 \\
\hline 27 & I & 2 & 3 & endo & pos & 7 & 237 & ATG $>$ ATA & met>ile & 39 & 61 & 3 \\
\hline \multirow[t]{2}{*}{$8^{e}$} & I & 3 & 3 & ser & pos & 7 & 260 & $\mathrm{TCC}>\mathrm{TCT}$ & ser>ser & 49 & 84 & 3 \\
\hline & & & & & & 8 & 306 & CGA $>$ TGA & arg>stop & & & \\
\hline 14 & I & 1 & 3 & ser & pos & 8 & 267 & $C G G>C A G$ & $\arg >g \mid n$ & 51 & 25 & 3 \\
\hline 13 & I & 4 & 3 & ser & pos & 8 & 273 & CGT>AGT & $\arg >$ ser & 39 & 15 & 3 \\
\hline 29 & I & 3 & 3 & $\operatorname{mix}$ & pos & 8 & 273 & CGT $>$ TGT & $\arg >$ cys & 50 & 36 & 3 \\
\hline 2842 & 11 & 4 & 3 & ser & pos & 8 & 273 & CGT>TGT & arg>cys & 39 & 35 & 3 \\
\hline 21 & I & 3 & 3 & ser & pos & 8 & 293 & GGG $>A G G$ & $g \mid y>\arg$ & 39 & 21 & 3 \\
\hline 26 & I & 3 & 2 & ser & pos & & intron & $G>A$ & ivs5 & 53 & 93 & I \\
\hline 9 & I & 4 & 2 & ser & neg & & & & & 50 & 39 & 3 \\
\hline II & I & 3 & 3 & ser & neg & & & & & 44 & 8 & 3 \\
\hline 17 & I & 3 & 3 & ser & neg & & & & & 47 & 30 & 3 \\
\hline 24 & I & 2 & 4 & ser & neg & & & & & 59 & 20 & 3 \\
\hline 34 & I & 1 & 3 & ser & neg & & & & & 46 & 120 & I \\
\hline 30 & I & I & 2 & ser & neg & & & & & 43 & 199 & 2 \\
\hline 32 & I & 2 & 3 & ser & neg & & & & & 48 & 108 & I \\
\hline 3351 & I & 4 & 3 & endo & neg & & & & & 44 & 9 & 3 \\
\hline I & 2 & 4 & 3 & ser & pos & 5 & 144 & CAG $>T A G$ & gln>stop & 41 & I & 3 \\
\hline 3 & 2 & 3 & 3 & uncl & pos & 6 & 196 & CGA $>T G A$ & arg>stop & 48 & 46 & 3 \\
\hline 20 & 2 & 3 & 3 & ser & pos & 6 & 205 & $\mathrm{TAT}>\mathrm{TCT}$ & tyr $>$ ser & 52 & 36 & 3 \\
\hline 28 & 2 & 4 & 3 & ser & pos & 7 & 261 & $A G G>A G A$ & $\arg >\arg$ & 80 & 12 & 3 \\
\hline \multirow[t]{2}{*}{$7 e$} & 2 & 3 & 3 & ser & pos & 7 & 255 & ATC $>$ GTC & ile>val & 58 & 30 & 3 \\
\hline & & & & & & 5 & 141 & TGC $>$ TGT & cys > cys & & & \\
\hline 12 & 2 & 1 & 3 & ser & pos & 8 & 280 & $A G A>G G A$ & arg $>$ gly & 49 & 134 & I \\
\hline 15 & 2 & 3 & 3 & ser & pos & & intron & $C>T$ & ivs7 & 50 & 19 & 3 \\
\hline 5 & 2 & 4 & 3 & ser & neg & & & & & 60 & 45 & 3 \\
\hline 18 & 2 & 2 & 3 & endo & neg & & & & & 44 & 117 & 3 \\
\hline 22 & 2 & 3 & 2 & mix & neg & & & & & 47 & 96 & 3 \\
\hline
\end{tabular}

a: $I=1675$ delA and $2=1 \mid$ 35insA. b: undifferentiated (4). c: all patients were followed until diseased or to I5th April, 2004. d: alive without cancer (I), alive with cancer (2), and dead by cancer (3). e: two different mutations detected in sample.

nonsense, three were silent sequence changes (not previously reported as polymorphisms) and two were intronic sequence changes of unknown function.

The frequency of transitions vs. transversion in this hereditary cohort $(85.7 \%$ and $14.3 \%)$ was also quite similar to that reported in the IARC database for sporadic cases ( $88 \%$ and $12 \%$ ), but differed slightly from the sporadic cases in this study $(76.4 \%$ and $23.6 \%)$. The frequency of mutations likely to cause protein alteration were $68.0 \%$ $(68 / 100)$ for the sporadic cases and $53.3 \%(16 / 30)$ for the familial cases. The TP53 mutation frequency in the two different BRCA1 carriers differed slightly with 11/20 $(55.0 \%)$ in the BRCA1 1675delA carriers and 5/10 $(50.0 \%)$ in the BRCA1 1135insA carriers. The 1675delA carriers had $7.7 \%$ transversions and $92.3 \%$ transitions while the 1135 insA carriers had $12.5 \%$ transversion and $82.5 \%$ transitions. Four of the TP53 mutations were novel and not previously reported in ovarian cancer in the IARC
TP53 Database [35] or the SOUSSI database. These mutations affected codon 205 (tyr >ser), 260 (ser>ser), 267 (arg>gln) and 293 (gly>arg). All mutations detected resided in exons 5-8. When comparing the TP53 mutation spectrum in these familial cases with that of ovarian cancers cases reported in the IARC database and to the 100 sporadic ovarian cancer cases with a TP53 mutation, no obvious differences were seen either with respect to exon distribution or codon wise (data not shown), although a slightly lower frequency of mutations in exon 5 and a slightly higher in exon 8 were seen in the hereditary cases. The TP53 mutations in the 100 sporadic cases used in this study is reported elsewhere [29].

\section{Age at diagnosis, survival, BRCAI and TP53 status}

Median age at diagnosis among sporadic cases and familial cases that carried 1675delA or 1135insA mutations is presented in Table 1. As expected, the familial cases are diagnosed earlier in life than sporadic cases $(p<0.001)$. 
Table 3: Hazard risk of TP53 mutations on familial and sporadic ovarian cancer cases.

\begin{tabular}{ccccc}
\hline & \# cases & HR & Cl (95\%) & P-value \\
\hline Familial Cases & 30 & & & \\
TP53 no mutation & 14 & I (ref) & $0.71-3.78$ & 0.25 \\
TP53 mutation & 16 & 1.64 & & \\
Sporadic cases & 100 & $\mathrm{I}($ ref) & $0.55-1.66$ & 0.88 \\
TP53 no mutation & 26 & 0.96 & \\
TP53 mutation & 76 & & \\
\hline
\end{tabular}

The difference in median age of onset between the 1135 ins $A$ and 1675 delA mutation carriers was not significant $(\mathrm{p}=0.245)$.

In the univariate analysis of the combined group, neither $B R C A 1$ status nor age at diagnosis was significantly associated to survival $(\mathrm{p}=0.87$ and $\mathrm{p}=0.50$ for $B R C A 1$ status and age at diagnosis (categorized into $<50$ and $\geq 50$ years), respectively). TP53 mutation did not significantly reduce the survival rates $(\mathrm{p}=0.35)$. Notably, interaction between BRCA1 status and TP53 status was borderline significant (test for interaction: $\mathrm{p}=0.06$ ) while the one between BRCA1 status and age at diagnosis was statistically significant (test for interaction: $\mathrm{p}=0.05$ ). We further analyzed these factors adjusted for tumor grade, however, results did not substantially change (test interaction: $\mathrm{p}=$ 0.04 and $\mathrm{p}=0.05$ for BRCA $1{ }^{*}$ TP53 and BRCA $1 *$ age at diagnosis, respectively).

No association between age at diagnosis and survival time was found among sporadic cases $(\mathrm{p}=0.88)$. Familial cases with late age at diagnosis ( $\geq 50$ years) had a slightly higher risk of dying than the cases with an early age at diagnosis, however the association did not reach significance, possibly due to a lack of statistical power $(\mathrm{RR}=1.65,95 \% \mathrm{CI}$ [0.79-3.43], $\mathrm{p}=0.14)$. Among cases diagnosed at age 50 years or more, familial cases had a trend towards a higher risk of dying than sporadic cases $(\mathrm{RR}=1.75,95 \% \mathrm{CI}$ [0.93-3.30], $\mathrm{p}=0.08)$. After adjustment for the effect of tumor grade and TP53 status (RR $=1.80,95 \%$ CI [0.943.43], $\mathrm{p}=0.08$ ) (data not shown). Table 3 shows the risk ratios associated to TP53 mutations after stratification for BRCA1 status.

There was no significant difference in survival observed among TP53 mutations carriers compared to non-TP53 mutations carriers, neither for the familial nor the sporadic cases (Log-rank test for TP53 in familial cases: $\mathrm{p}=$ 0.25 and log-rank test for TP53 in sporadic cases: $\mathrm{p}=0.88$ ) (Table 3).

\section{Discussion}

Some studies have reported an enhanced survival for BRCA1 carriers with ovarian cancer compared to sporadic cases [12-14,36,37], but these studies have not taken TP53 status in the tumors in to consideration. Other studies in which TP53 status have been included concludes that there is no difference in survival [16].

Our results do not show an enhanced survival rate for familial cases compared to sporadic cases, even after adjustment for TP53 status when all age groups were included. Further, no significant difference in survival rates was observed between the familial cases with and without TP53 mutations (Table 3).

These results do not support earlier observations regarding the importance of the p53/BRCA1 interaction on cell proliferation and ovarian carcinogenesis. Most penetrance estimates and survival rates are based on studies in populations with strong founder effects, and may therefore be biased [15-17,38]. Two Ashkenazi founder mutations occur in BRCA1 185delAG and 5382insC (carrier frequencies of $0.9 \%$ and $0.13 \%$ ), with mean age at diagnosis 54 years. How the type of mutation in the BRCA1 gene affects survival, age at diagnosis of the disease, the response to environmental exposure causing DNA damage, and the efficiency of DNA repair, is not clarified. Heterozygote advantage or an increase in biological fitness conferred on carriers of a disease causing mutation (like BRCA1?), often a resistance to certain infections that were common in times past, can cause an increase in allele frequency [39]. Genetic factors with impact on survival and age at onset of disease, to after childbearing age, would be preferential.

The trend for an increased survival in favour of the early age at onset in familial cases compared to late age at onset in familial cases may be attributed to younger patients having greater physical strength, less somatic mutations, and manage illness better than older patients. On the other hand, one might also expect this trend in sporadic cases, which was not the case. One limitation of our study 
is the small numbers of $B R C A 1$ carriers. In our study, the statistical power to detect $B R C A 1$ effect was $76 \%$.

Consequently, our findings should be confirmed in larger studies. The conflicting literature on the impact of BRCA1 mutation status on ovarian cancer survival should promote additional studies from different ethnic populations, and thereby allow investigators to study whether or not there is a survival benefit due to BRCA1 mutation, or may be secondary to other common inherited genetic factors, which may be shared in ethnic or geographic isolated populations.

Alterations in the TP53 gene have been shown to affect breast cancer survival and in particular patients with mutations in the zinc-binding domains have poor survival [40]. In sporadic ovarian carcinoma several studies reports that no or little effect of TP53 mutations have been seen $[17,24,28]$, which is similar to the results reported here. TP53 alterations are also suggested to alter ovarian cancer survival in BRCA1 germ line patients $[13,14]$, while other groups concludes with a failure of BRCA1 dysfunction to alter ovarian cancer survival [16]. It should also be noted that a considerable fraction (60-80\%) of all familial BRCA1 ovarian cancers harbor TP53 mutations $[18,19,21,22]$. Only a few studies have reported analysis of TP53 mutations in relation to BRCA1 associated ovarian cancer $[20,41]$. The present study is the first investigating somatic TP53 mutations in ovarian tumors from carries of two distinct high penetrant BRCA1 germ-line mutations, relating it to survival and age at diagnosis of disease and compares it to sporadic cases. We have previously studied the distribution in age at diagnosis in BRCA1 carriers and non-carriers as a part of a cohort study. Three percent of Norwegian ovarian cancers are caused by BRCA1 1675delA or 1135insA [31,42], with a distribution similar to that found in this study (Table 1). Further, Bjørge et al. [43] found that $87.0 \%$ of Norwegian sporadic ovarian cancers was papillary serous adenocarcinoma, an aggressive histo-prognostic factor.

Eigthy percent of both familial and sporadic ovarian cancer cases in this study were papillary serous adenocarcinoma. Questions need to be addressed concerning the clinical effects of mutations in the BRCA1 gene, why some mutation carriers develop breast cancer, others develop ovarian cancer, and some develop both. We do not know whether the cancers occurring in mutation carriers are significantly different from those occurring in non carriers. The frequency of TP53 mutations in the familial cases altering the protein was $53.3 \%$, which is somewhat higher than other studies of familial BRCA1 ovarian cancer (31$50 \%$ ) [18-22,24,25]. Although the number of familial cases in this study is limited, a slightly higher frequency of mutations was found in exon 8 and a lower frequency in exon 5 compared to sporadic cases in the IARC database. The same tendency has been reported by others [20]. However, a non-significant difference in TP53 mutation frequency was observed between the familial and sporadic cases in this study.

Of the novel mutations found in the familial cohort the codon 205 mutation has previously been reported in several other tumors like head and neck SCC as well as breastand colorectal carcinoma. The amino acid change in codon 255 and 293 are only reported once, in oesophageal SCC and bladder cancer, respectively. The silent codon 260 mutation are reported in two different cancer tissues; lung (SCLC) and colorectal carcinoma. Environmental exposure, both external and internal, is known to influence the spectrum of mutations. Whether hormonal disturbance may affect the mutation rate and spectrum is not known, but if so, it may be expected that BRCA1 carriers are more sensitive to such exposure.

\section{Conclusion}

Interestingly, no difference in survival was observed between TP53 mutation carriers among the familial carries or among the sporadic cases (Table 3 ). Further, we did not find an overall difference in survival between familial BRCA1 carriers and sporadic epithelial ovarian cancer cases, even after adjustment for TP53 status. For cases diagnosed over the age 50 there was a trend toward higher survival for sporadic cases.

\section{List of abbreviations}

TTGE; temporal temperature gradient gel electrophoresis; PCR, polymerase chain reaction; FIGO, International Federation of Gynaecology and Obstetrics. RR; risk ratio.

\section{Competing interests}

The author(s) declare that they have no competing interests.

\section{Authors' contributions}

PK participated in the design of the study, carried out the molecular genetic studies, sequence alignment and drafted the manuscript. YW participated in screening of the sporadic cases and sequence alignment. VD performed the statistical analyses. GK performed clinical updates of sporadic cases.

JMN evaluated pathology sections of sporadic and familial cases. ALBD conceived the study, participated in its design and helped draft the manuscript. AD conceived the study, performed clinical dates of the familial cases and helped draft the manuscript. All authors read and approved the final manuscript. 


\section{Acknowledgements}

Pedro Kringen is a research fellow of The Norwegian Cancer Society. Guro Elisabeth Lind is acknowledged for working out the optimal condition for DNA extraction from paraffin embedded tissues. We thank Sigrid Lystad and Phuong $\mathrm{Vu}$ for providing excellent technical assistance.

This work was supported by grants from The Norwegian Cancer Society and The Norwegian Research Council.

\section{References}

I. The Norwegian Cancer Registry: Cancer in Norway 1998. The Cancer Registry of Norway [http://www.kreftregisteret.nol]].

2. Engeland A, Haldorsen T, Tretli S, Hakulinen T, Horte LG, Luostarinen T, Magnus K, Schou G, Sigvaldason H, Storm HH, et al.: Prediction of cancer incidence in the Nordic countries up to the years 2000 and 2010 . A collaborative study of the five Nordic Cancer Registries. APMIS Suppl 1993, 38:I-I24.

3. Zweemer RP, Verheijen RH, Menko FH, Gille JJ, van Diest PJ, Coebergh JW, Shaw PA, Jacobs IJ, Kenemans P: Differences between hereditary and sporadic ovarian cancer. Eur J Obstet Gynecol Reprod Biol 1999, 82(2): I5I-I53.

4. Miki Y, Swensen J, Shattuck-Eidens D, Futreal PA, Harshman K, Tavtigian S, Liu Q, Cochran C, Bennett LM, Ding W, et al.: A strong candidate for the breast and ovarian cancer susceptibility gene BRCAI. Science 1994, 266(5 I82):66-7I.

5. Wooster R, Bignell G, Lancaster J, Swift S, Seal S, Mangion J, Collins N, Gregory S, Gumbs C, Micklem G: Identification of the breast cancer susceptibility gene BRCA2. Nature 1995, 378(6559):789-792.

6. Boyd J: Molecular genetics of hereditary ovarian cancer. Oncology (Huntingt) 1998, I 2(3):399-406; discussion 409-10, 413.

7. Lynch HT, Watson P, Lynch JF, Conway TA, Fili M: Hereditary ovarian cancer. Heterogeneity in age at onset. Cancer 1993, 7 I(2 Suppl):573-58I.

8. Ford D, Easton DF, Peto J: Estimates of the gene frequency of BRCAI and its contribution to breast and ovarian cancer incidence. Am J Hum Genet 1995, 57(6): | 457- 1462.

9. Ford D, Easton DF, Stratton M, Narod S, Goldgar D, Devilee P, Bishop DT, Weber B, Lenoir G, Chang-Claude J, Sobol H, Teare MD, Struewing J, Arason A, Scherneck S, Peto J, Rebbeck TR, Tonin P, Neuhausen S, Barkardottir R, Eyfjord J, Lynch H, Ponder BA, Gayther $S A$, Zelada-Hedman M, et al.: Genetic heterogeneity and penetrance analysis of the BRCAI and BRCA2 genes in breast cancer families. The Breast Cancer Linkage Consortium. Am J Hum Genet 1998, 62(3):676-689.

10. Dorum A, Heimdal K, Hovig E, Inganas M, Moller P: Penetrances of BRCAI 1675delA and II35insA with respect to breast cancer and ovarian cancer. Am J Hum Genet 1999, 65(3):67I-679.

II. Dorum A, Moller P, Kamsteeg EJ, Scheffer H, Burton M, Heimdal KR, Maehle LO, Hovig E, Trope CG, van der Hout AH, van der Meulen MA, Buys CH, te Meerman GJ: A BRCAI founder mutation, identified with haplotype analysis, allowing genotype/phenotype determination and predictive testing. Eur J Cancer 1997, 33(I4):2390-2392.

12. Rubin SC, Benjamin I, Behbakht K, Takahashi H, Morgan MA, LiVolsi VA, Berchuck A, Muto MG, Garber JE, Weber BL, Lynch HT, Boyd J: Clinical and pathological features of ovarian cancer in women with germ- line mutations of BRCAI. N Engl J Med 1996, 335(19): 1413-1416.

13. Ben David Y, Chetrit A, Hirsh-Yechezkel G, Friedman E, Beck BD, Beller U, Ben-Baruch G, Fishman A, Levavi H, Lubin F, Menczer J, Piura B, Struewing JP, Modan B: Effect of BRCA mutations on the length of survival in epithelial ovarian tumors. J Clin Oncol 2002, 20(2):463-466.

14. Cass I, Baldwin RL, Varkey T, Moslehi R, Narod SA, Karlan BY: Improved survival in women with BRCA-associated ovarian carcinoma. Cancer 2003, 97(9):2187-2195.

15. Johannsson OT, Ranstam J, Borg A, Olsson H: Survival of BRCAI breast and ovarian cancer patients: a population-based study from southern Sweden. J Clin Oncol 1998, 16(2):397-404.

16. Buller RE, Shahin MS, Geisler JP, Zogg M, De Young BR, Davis CS: Failure of BRCAI dysfunction to alter ovarian cancer survival. Clin Cancer Res 2002, 8(5): I | $96-1202$.
17. Smith-Sorensen B, Kaern J, Holm R, Dorum A, Trope C, BorresenDale AL: Therapy effect of either paclitaxel or cyclophosphamide combination treatment in patients with epithelial ovarian cancer and relation to TP53 gene status. $\mathrm{Br}$ J Cancer 1998, 78(3):375-381.

18. Ramus SJ, Bobrow LG, Pharoah PD, Finnigan DS, Fishman A, Altaras M, Harrington PA, Gayther SA, Ponder BA, Friedman LS: Increased frequency of TP53 mutations in BRCAI and BRCA2 ovarian tumours. Genes Chromosomes Cancer 1999, 25(2):91-96.

19. Tworek H, Peng R, Fetzer S, Werness BA, Piver MS, Allen HJ, DiCioccio RA: Mutation analysis of BRCAI, TP53, and KRAS2 in ovarian and related pelvic tumors. Cancer Genet Cytogenet 1999. I I2(2): 105-II8.

20. Buller RE, Lallas TA, Shahin MS, Sood AK, Hatterman-Zogg M, Anderson B, Sorosky Jl, Kirby PA: The p53 mutational spectrum associated with BRCAI mutant ovarian cancer. Clin Cancer Res 200I, 7(4):83I-838.

21. Rhei E, Bogomolniy F, Federici MG, Maresco DL, Offit K, Robson ME, Saigo PE, Boyd J: Molecular genetic characterization of BRCAI- and BRCA2-linked hereditary ovarian cancers. Cancer Res 1998, 58(15):3193-3196.

22. Schorge JO, Muto MG, Lee SJ, Huang LW, Welch WR, Bell DA, Keung EZ, Berkowitz RS, Mok SC: BRCAI-related papillary serous carcinoma of the peritoneum has a unique molecular pathogenesis. Cancer Res 2000, 60(5): | $36 \mid-1364$.

23. Wertheim I, Muto MG, Welch WR, Bell DA, Berkowitz RS, Mok SC: p53 gene mutation in human borderline epithelial ovarian tumors. J Natl Cancer Inst 1994, 86(20): I549-I55I.

24. Fallows S, Price J, Atkinson RJ, Johnston PG, Hickey I, Russell SE: P53 mutation does not affect prognosis in ovarian epithelial malignancies. J Pathol 200I, I 94(I):68-75

25. Ozalp S, Yalcin OT, Minsin TH: Expression of p53 in epithelial ovarian cancer. Int J Gynaecol Obstet 2000, 7 I(3):277-278.

26. Ludwig T, Chapman DL, Papaioannou VE, Efstratiadis A: Targeted mutations of breast cancer susceptibility gene homologs in mice: lethal phenotypes of Brcal, Brca2, Brcal/Brca2, Brcal/p53, and Brca2/p53 nullizygous embryos. Genes Dev 1997, II (I 0): |226-I24I.

27. Sourvinos G, Spandidos DA: Decreased BRCAI expression levels may arrest the cell cycle through activation of p53 checkpoint in human sporadic breast tumors. Biochem Biophys Res Commun 1998, 245(I):75-80

28. Wang Y, Helland A, Holm R, Skomedal H, Abeler VM, Danielsen HE, Trope CG, Borresen-Dale AL, Kristensen GB: TP53 mutations in early-stage ovarian carcinoma, relation to long-term survival. Br J Cancer 2004, 90(3):678-685.

29. Wang Y, Kringen P, Kristensen GB, Holm R, Baekelandt MM, Olivier M, Skomedal H, Hainaut P, Trope CG, Abeler VM, Nesland JM, Borresen-Dale AL, Helland A: Effect of the codon 72 polymorphism (c.215G>C, p.Arg72Pro) in combination with somatic sequence variants in the TP53 gene on survival in patients with advanced ovarian carcinoma. Hum Mutat 2004, 24(I):2I-34.

30. Andersen TI, Borresen AL, Moller P: A common BRCAI mutation in Norwegian breast and ovarian cancer families? $\mathrm{Am} J$ Hum Genet 1996, 59(2):486-487.

31. Dorum A, Hovig E, Trope C, Inganas M, Moller P: Three per cent of Norwegian ovarian cancers are caused by BRCAI I675delA or I I35insA. Eur J Cancer 1999, 35(5):779-78I.

32. Borg A, Dorum A, Heimdal K, Maehle L, Hovig E, Moller P: BRCAI 1675delA and I I35insA account for one third of Norwegian familial breast-ovarian cancer and are associated with later disease onset than less frequent mutations. Dis Markers 1999 , I5(I-3):79-84.

33. Miller SA, Dykes DD, Polesky HF: A simple salting out procedure for extracting DNA from human nucleated cells. Nucleic Acids Res 1988, 16(3): 1215.

34. Sorlie T, Johnsen H, Vu P, Lind GE, Lothe R, Borresen-Dale AL: Mutation Screening of the TP53 Gene by Temporal Temperature Gradient Gel Electrophoresis. Methods Mol Biol 2004, 291:207-216

35. Olivier M, Eeles R, Hollstein M, Khan MA, Harris CC, Hainaut P: The IARC TP53 database: new online mutation analysis and recommendations to users. Hum Mutat 2002, 19(6):607-614.

36. Zweemer RP, Shaw PA, Verheijen RM, Ryan A, Berchuck A, Ponder BA, Risch H, McLaughlin JR, Narod SA, Menko FH, Kenemans P, 
Jacobs IJ: Accumulation of $\mathrm{p} 53$ protein is frequent in ovarian cancers associated with BRCA1 and BRCA2 germline mutations. J Clin Pathol 1999, 52(5):372-375.

37. Zweemer RP, Verheijen RH, Coebergh JW, Jacobs IJ, van Diest PJ, Gille JJ, Skates S, Menko FH, Ten Kate LP, Kenemans P: Survival analysis in familial ovarian cancer, a case control study. Eur Obstet Gynecol Reprod Biol 200I, 98(2):219-223.

38. Goldgar DE, Reilly PR: A common BRCAI mutation in the Ashkenazim. Nat Genet 1995, I I(2): I I3- I I4.

39. Offman J, Opelz G, Doehler B, Cummins D, Halil O, Banner NR Burke MM, Sullivan D, Macpherson P, Karran P: Defective DNA Mismatch Repair in Acute Myeloid Leukemia/Myelodysplastic Syndrome After Organ Transplantation. Blood 2004.

40. Borresen AL, Andersen TI, Eyfjord JE, Cornelis RS, Thorlacius S, Borg A, Johansson U, Theillet C, Scherneck S, Hartman S, et al.: TP53 mutations and breast cancer prognosis: particularly poor survival rates for cases with mutations in the zinc-binding domains. Genes Chromosomes Cancer 1995, I 4(I):7I-75.

4I. Buller RE, Sood AK, Lallas T, Buekers T, Skilling JS: Association between nonrandom $X$-chromosome inactivation and BRCA I mutation in germline DNA of patients with ovarian cancer [see comments]. J Natl Cancer Inst I999, 9 I(4):339-346.

42. Bjorge T, Engeland A, Sundfor K, CG. T: Prognosis of 2,800 patients with epithelial ovarian cancer diagnosed during 1975-94 and treated at the Norwegian Radium Hospital. Acta Obstet Gynecol Scand 1998, 77(7):777-78I.

43. Bjorge T, Engeland A, Hansen S, Trope CG: Prognosis of patients with ovarian cancer and borderline tumours diagnosed in Norway between 1954 and 1993. Int / Cancer 1998, 75(5):663-670.

\section{Pre-publication history}

The pre-publication history for this paper can be accessed here:

http://www.biomedcentral.com/1471-2407/5/134/pre pub
Publish with Bio Med Central and every scientist can read your work free of charge

"BioMed Central will be the most significant development for disseminating the results of biomedical research in our lifetime. "

Sir Paul Nurse, Cancer Research UK

Your research papers will be:

- available free of charge to the entire biomedical community

- peer reviewed and published immediately upon acceptance

- cited in PubMed and archived on PubMed Central

- yours - you keep the copyright
BioMedcentral 